\title{
DEVELOPING MOODLE - BASED \\ INTERACTIVE ONLINE MEDIA TO \\ TEACH NARRATIVE READING IN SMA N \\ 13 SEMARANG
}

\author{
Miftakul Nikmah \\ Undergraduate Program of UIN Walisongo
}

\begin{abstract}
This research employs research and development model. The conducted development was the interactive online media based e-learning of English subject with the Moodle application in SMA N 13 Semarang. Moodle (Modular Object-Oriented Dynamic Learning Environment) is a course management system for online learning using PHP and MySQL. The learning instrument development design was carried out using the six steps of Borg and Gall model. They were need analysis, planning, developing preliminary Moodle-based interactive online media, preliminary field testing, Moodle-based interactive online media revision, and main field testing. The data collecting techniques used in this research were interview, questionnaire and documentation. The developing result of interactive online media Moodle-based to teach narrative reading could be accessed at http://www.elen.airybelle. com.
\end{abstract}

Key words: developing interactive online media, Moodle, narrative reading 


\section{Introduction}

E-learning involves all forms of ICT, across all dimensions of the learning processes. E-learning can be both a distinct area of study and part of the wider mosaic of learning, knowledge management and information exchange within electronic environment (Allan, 2003). Today e-learning refers to a mixture of technologies that are often encapsulated within an environment or management system. Early online or virtual learning environments allowed students to interact with content, fellow students, and faculty within the one web site. In addition, students can create content within the virtual environment. These are now referred to as Learning Management Systems (LMS), virtual learning environments, or course management systems (Richard, 2008).

English is one of the international languages used in country throughout the world, including Indonesia. As the first language, English is taught as a compulsory subject from junior high school up to senior high school in today's Indonesian educational system. But in fact, English as a foreign language is considered as one of the most difficult lessons. In our country, "students are usually afraid of joining foreign language classes" (Siti, 2008). In applied language over the last decades, it has been common to divide language into the four skills and then to add grammar, vocabulary and phonology to them (Cameron, ). It is applied in teaching language at senior high school includes four language skills; listening, speaking, reading, and writing. Those four skills are taught in an integrated manner.

The researcher is interested in conducting a research in SMA Negeri 13 Semarang because there were many facilities in the school especially in using internet, but the teachers did not use it effectively. There was hot spot area but it was not used well in teaching and learning process. The computer laboratory was also connected to internet which had 35 personal computers. There were 10 computers connected to internet in the teacher's room and 2 computers connected to internet in the library. Beside the computer laboratory, internet could also be accessed in almost all areas in the school which would be the main proponent in this research. As we know 
internet had many benefits such applications as e-mail, instant messaging, audio and video streaming, Web browsing, and e-commerce and others (Apostolis, 2004). But, the teachers only asked students to search the tasks from the internet and then sending it by email. The English teachers used explaining method, repeating words or sentences and answering questions. It caused not all students did not enjoy the teaching and learning process. So, they did not understand the material and did not achieve the minimum score (75).

Based on the theory of the importance of e-learning, the internet advantages and the problem of teaching reading, the researcher would conduct a research on applying e-learning by using Learning Management System to solve those problems. She chose to apply e-learning Moodle-based to teach narrative reading in SMA Negeri 13 Semarang for tenth grade.

\section{Research Method}

This research is undertaken to develop Moodle-based interactive online media to teach narrative reading. To gain the purpose, it is needed a research approach that highlights an effort to produce the interactive online media. Therefore, in designing the model, the researcher used Research and Development approach by adapting Borg and Gall Model. Borg and Gall model consists of ten major steps but the researcher just took six steps. They are as follows. 


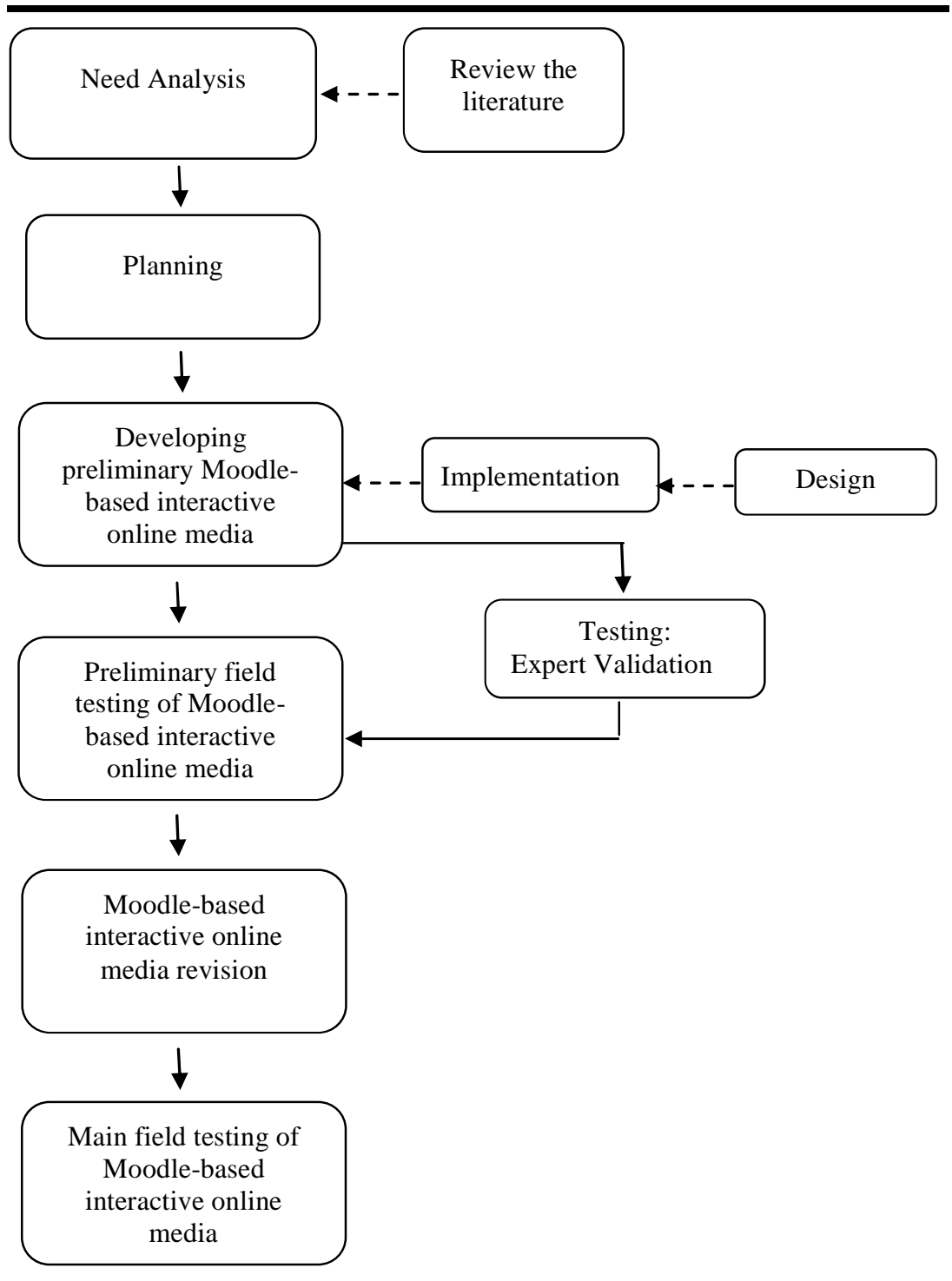

Figure 1: Borg and Gall model steps scheme

The first step was need analysis. This step was done to search information on how important was the product would be developed. It consisted of review the literature. After the initial planning has been completed, the next major step in the R \& D cycle is to build a preliminary form of the educational product that can be field testing. To develop Moodle, it was needed a standard of software 
development. ISO/IEC 12207 is an international standard for software life-cycle processes. It aims to be the standard that defines all the tasks required for developing and maintaining software. In software development, there is a standard process called SDLC. The most popular one is Waterfall Model.

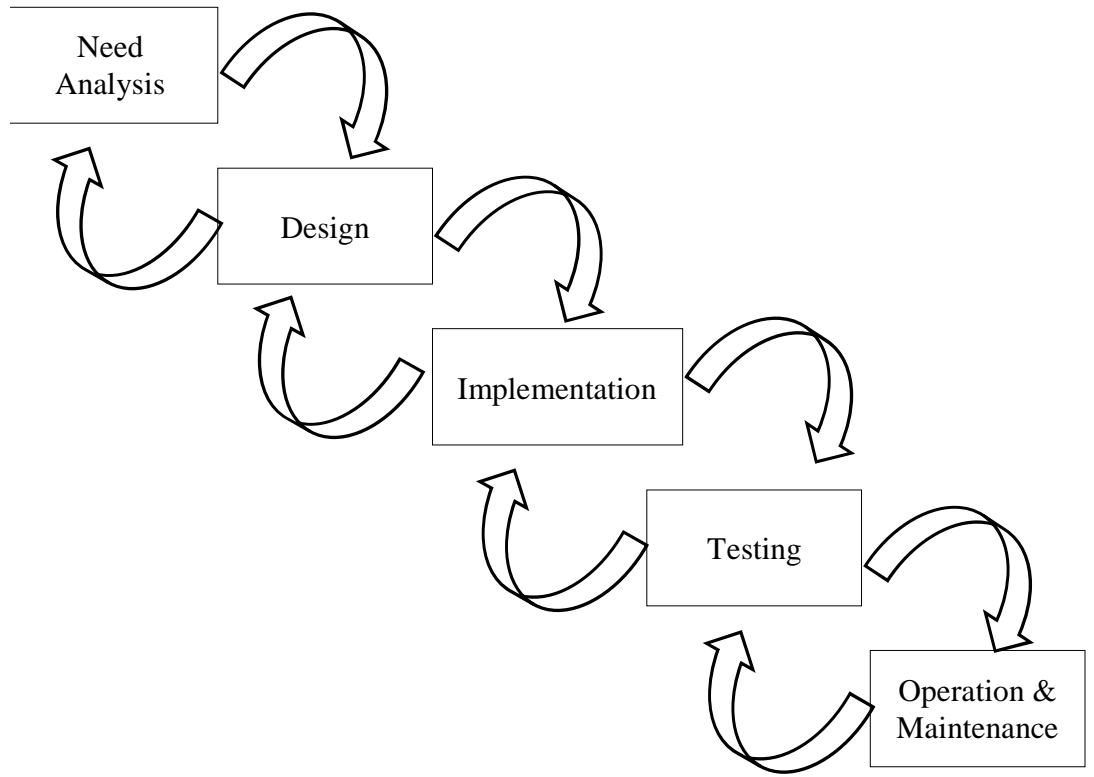

Figure 2.1 Waterfall software model

Related to developing Moodle-based interactive online media, need analysis was conducted to analyze functional and non-functional requirements. Design is the process of planning and problem solving for a software solution. One type of this process is interface design. Implementation refers to the realization of business requirements and design specifications into a concrete executable program, database, website, or software component through programming and deployment. Testing is also known as verification and validation which is a process for checking that a software solution meets the original requirements and specifications and that it accomplishes its intended purpose. Maintenance phase is an activity that aims to accommodate changes in order to produce a better performance. It is the process of modifying a 
software solution after delivery and deployment to refine output, correct errors, and improving performance and quality. (Bassil, 2012)

The next step was that the researcher designed the system planning of the interactive online media. It was implemented by using use case system diagram. In the use case system diagram, there are three actors related to this online media system. They are student, teacher and admin. Next, the researcher conducted the developing product. It was the product design that would be applied in field testing. The next step, the validation was done by online media expert of UIN Walisongo Semarang and the online media expert of SMAN 13 Semarang. Based on the inputs and evaluation experts, then the online media Moodle-based was revised to further improve quality and get a decent product to be applied

Preliminary field testing and main field testing were done in the different class. The purpose of the preliminary field test is to obtain an initial qualitative evaluation of the new educational product (Borg \& Gall, 1984). All phases of the R \& D cycle involve product evaluation. It is important to establish field sites similar to those in which the product will be used when it is fully developed. The purpose of the main field test in $\mathrm{R} \& \mathrm{D}$ cycle is to determine whether the product under development meets its performance objectives. Generally an experimental design is used to answer this question (Borg \& Gall, 1984).

The data collecting techniques in this research are interviewing, questionnaire, and documentation. The researcher will explain the three of them as follows.

The first technique was interviewing. Interviewing is as a foundation of knowledge upon which to develop a given educational product.

The second technique was questionnaire. The Questionnaire was divided into two parts. Questionnaire of validation and questionnaire of student's respond. The questionnaire of validation is for instructional design expert and teacher. It is made in order that the researcher knows some suggestions and revisions should be made by her. It was created to gather information about validity 
of the product prototype. Besides, it can help researcher know the weaknesses of the product. The questionnaire was given to the expert reviewer consisting of instructional design expert and teacher. They assess the prototype and give suggestion to revise the prototype. The test was undertaken from the questionnaire validation of the test expert. After the test was valid based on the questionnaire validation, the test would be given to the subjects.

The third technique was documentation. It is used to look for the data concerning matters or the variables that take the form of the note, transcript, book, newspaper, magazine, inscription, notes of a meeting, agenda, etc. The researcher used the documents related to the object of research such as students' name list and lesson plan.

Before the researcher used the instruments to collect data, the instruments were consulted to the instructor who guided her in conducting the research so that the content validity of the instrument can be achieved.

\section{Result and Discussion}

The result of Moodle-based interactive online media prototype was based on Borg and Gall model and it was matched with waterfall software model.

The need analysis was done to search information on how important was Moodle-based interactive online media would be developed. It consisted of review the literature. From the data of the interview, the researcher got a conclusion that English teachers did not employ yet in using internet effectively, whereas there was a training of e-learning process for the teachers in the school.

Moodle-based interactive online media as software used waterfall software model in its development. It used a use case diagram. A use case diagram is used to demonstrate the functionality of an entity such as a system, sub-system or class by using actors, use cases and the relationships between them. An actor was a set of roles that users can activity when interacting with the entity. A use case was a unit of behavior or functionality of an entity viewed from the perspective of the user (Mike, 2014). 


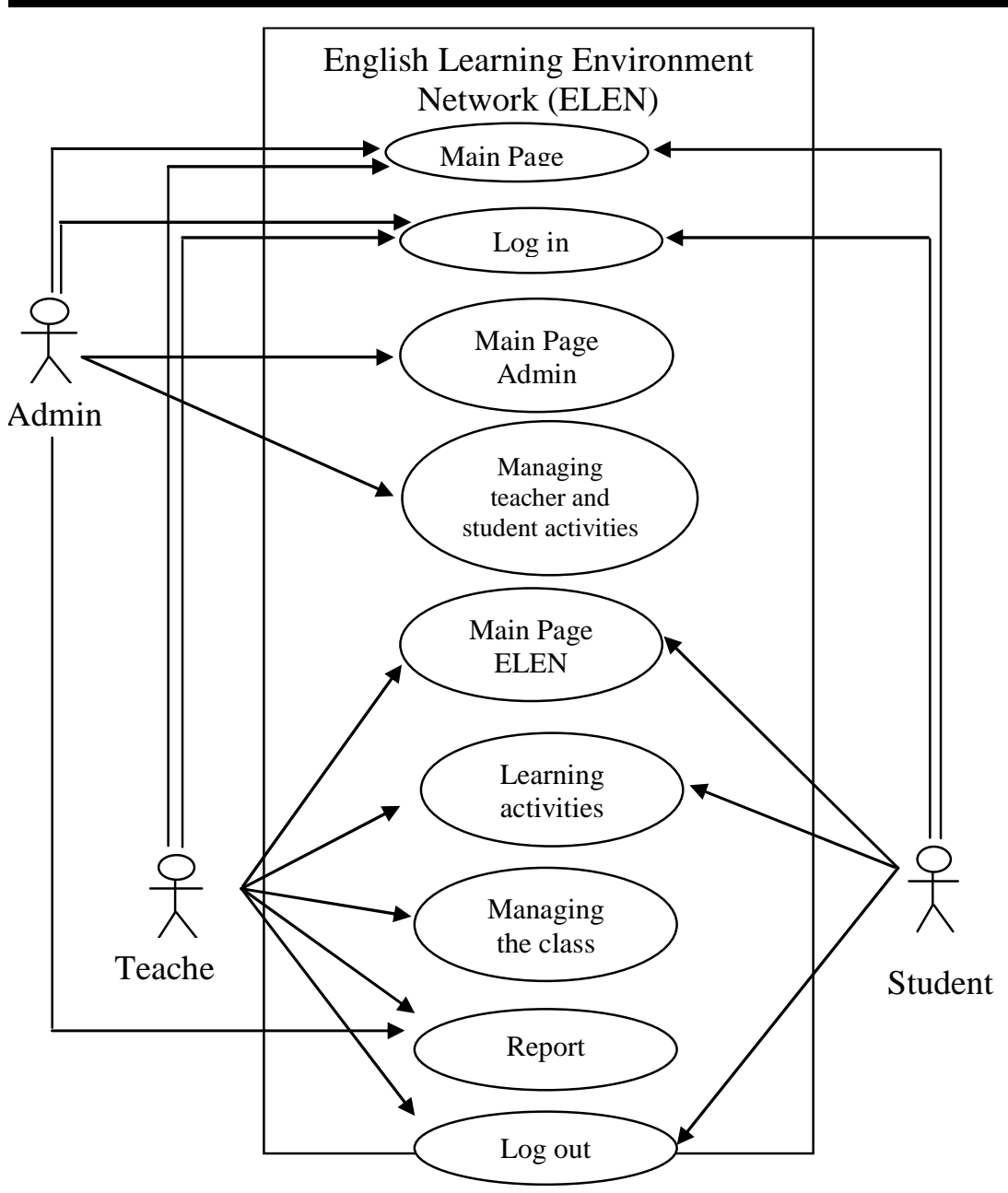

Figure 2: Use case diagram

From the diagram, it was able to be explained that there were three users who could access Moodle-based interactive online media ELEN. Users are anyone who uses the Moodle system. To participate in course, users need to be enrolled into course with a given role, such as: students, teacher and administrator. Once a user account is established, the primary Moodle administrator can change accounts login permissions. Following are types of user accounts that can be assigned to a Moodle user: Student (default - can interact with course content only), Teacher with Editing Permissions 
(can populate a course with activities and provide learner feedback - e.g. grades, assignment comments etc.), Teacher without Editing Permissions (can provide learner feedback only - e.g. grades, assignment comments etc). Administrator (can do anything and go anywhere within Moodle) (Bryan, 2005).

The planning concerned with the determining of users access field in this online media. There are three main users; administrator, teacher and students. Administrator could access main page admin and manage teacher and students activity after logged in. Teacher could access main page ELEN, learning activities, manage class and report after logged in. And student could access main page ELEN and learning activities.

The researcher also determined Bitnami local host for offline installation and purchased hosting and domain website. To access Moodle-based interactive online media by internet, it was needed a domain and web hosting to put the program files in web server. The specification of domain and web hosting Moodle-based interactive online media are as follows.

Table 1: Specification of domain and web hosting

\begin{tabular}{|l|l|}
\hline Main domain & airybelle.com \\
\hline Subdomain & elen.airybelle.com \\
\hline Disk Space & $500 \mathrm{MB}$ \\
\hline Monthly Bandwidth Transfer & $1.21 \mathrm{~GB} / 19.53 \mathrm{~GB}$ \\
\hline Apache version & 2.2 .27 \\
\hline PHP version & 5.4 .34 \\
\hline MySQL version & $5.5 .40-$ MariaDB \\
\hline Operating system & Linux \\
\hline
\end{tabular}

The next developing step was design and implementation of Moodle-based interactive online media. It could be explained to be some interface pages of Moodle-based interactive online media. Front page of Moodle-based system of interactive online media was the entry point for the user to the system. The function of this page was to provide login access to all users and general information on this website. After logging in the front page, user would go to course page. 
Interface design of each user access field is as follows.

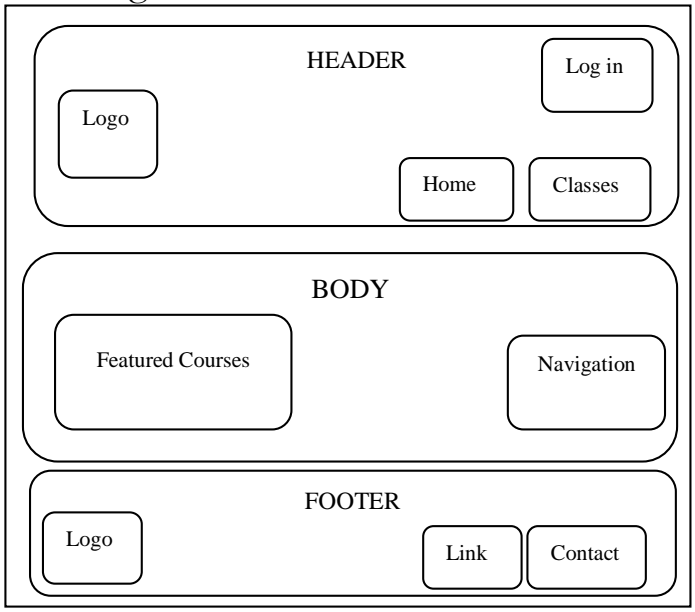

\section{Figure 3: Front page}

The page was divided into three sections. The top was header of the page. It consisted of logo picture, and button of log in, home and classes. The center was main course page, divided into featured courses and navigation block. The bottom was footer of the page which contained logo picture, links and contact info.

The user then continued to log in page based on the user access. They were administrator, teacher and student. For each front page, user page after they logged in would be delivered as follow.

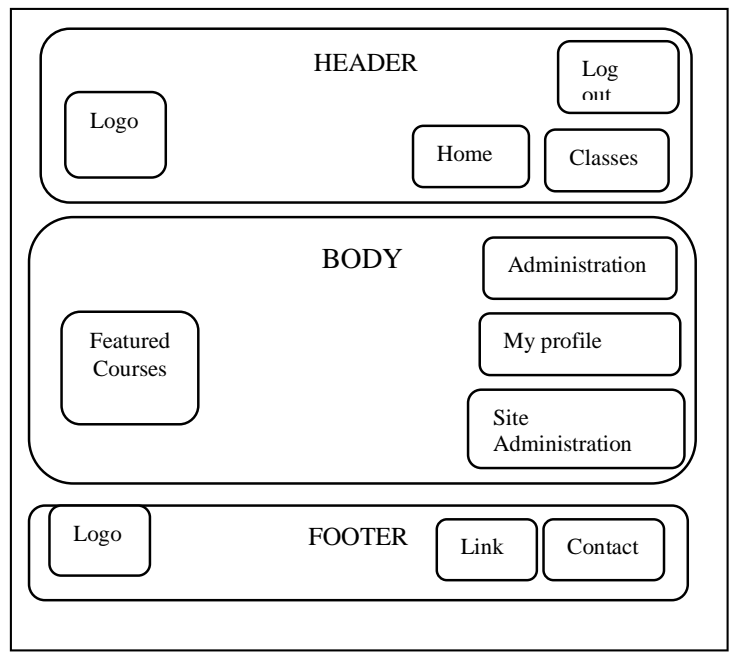

Figure 4: Admin front page 
The page was divided into three sections. The top was header of the page. It consisted of logo picture, and button of log out, home and classes. The center was body page, divided into featured courses and administration block, my profile and site administration setting. The bottom was footer of the page which contains logo picture, links and contact information.

The next user was teacher. He had same page access with the administrator. But there was not site administration setting.

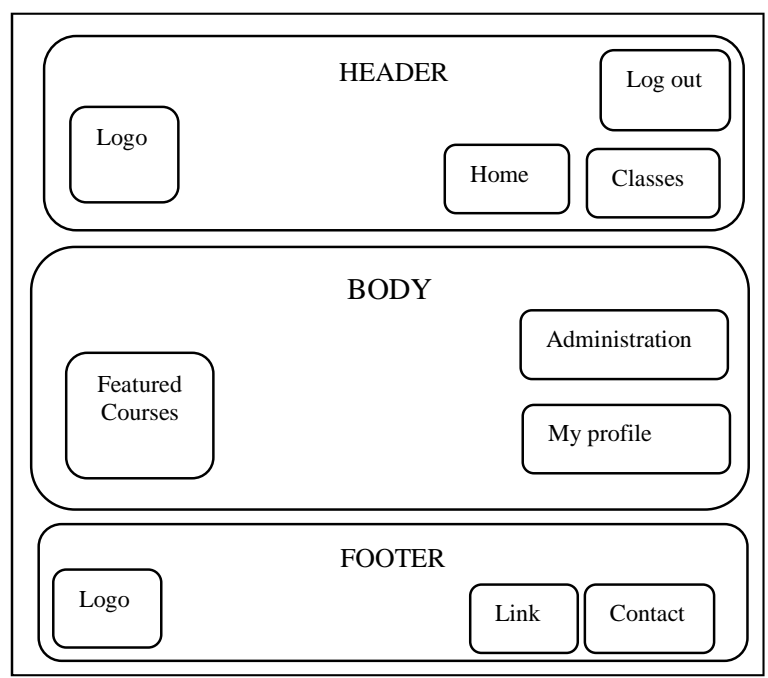

Figure 5: Teacher front page

The page was divided into three sections. The top was header of the page. It consisted of logo picture, and button of log out, home and classes. The center was body page, divided into featured courses, administration block and my profile setting. The bottom was footer of the page which contained logo picture, links and contact information.

The next user was student. He had same front page access with the teacher access. The administration setting of student had different content with the administration setting of teacher. 


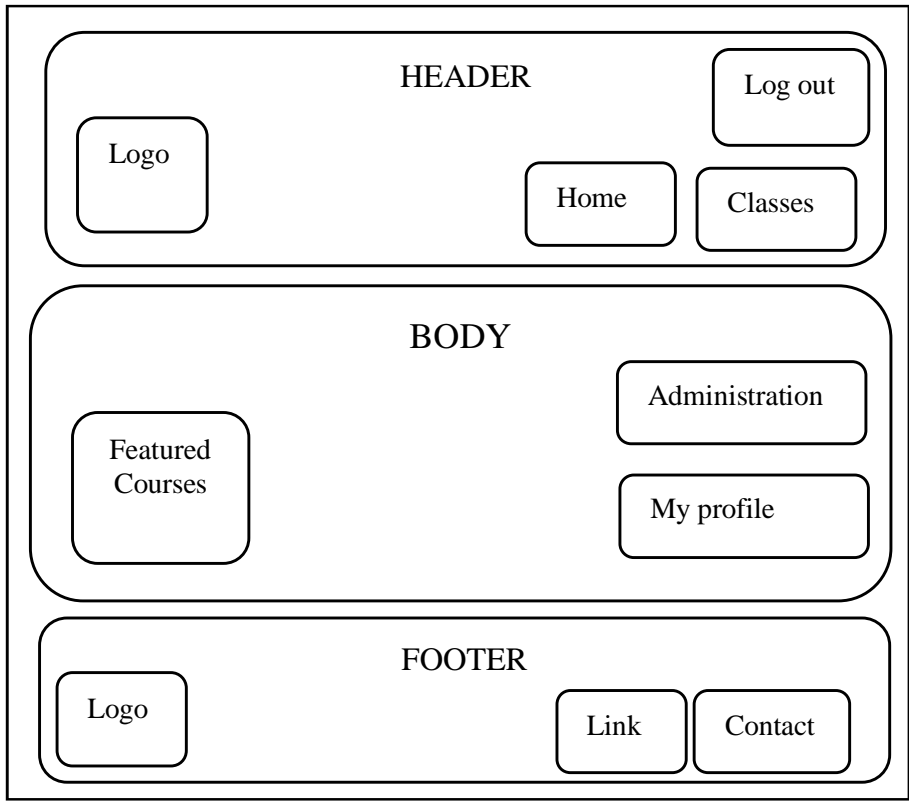

Figure 6: Student front page

The page was divided into three sections. The top was header of the page. It consisted of logo picture, and button of log out, home and classes. The center was body page, divided into featured courses and administration, my profile setting. The bottom was footer of the page which contains logo picture, links and contact information.

The implementation process was a step to realize the design which had been before. The front page of the website http: // elen.airybelle.com used default Moodle before it used a new theme. Theme developed from theme forest, namely Genesis theme. The captures of the site can be seen as below: 
Developing Moodle - Based Interactive Online Media ...

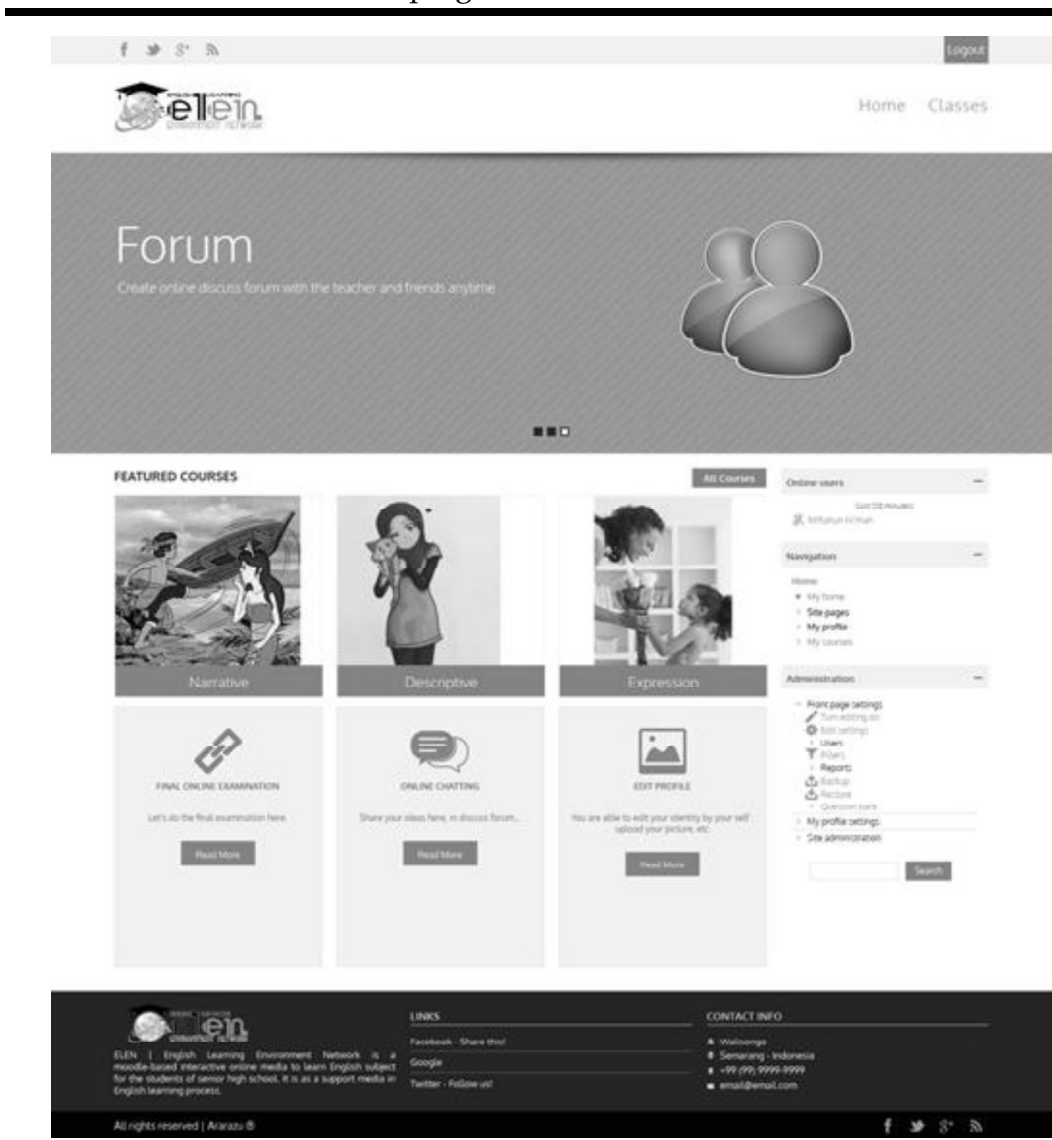

Figure 7: Admin front page.

The page was divided into three sections. The top was header of the page. It consisted of logo picture, and button of log in, home and classes. The center was body page, divided into featured courses and administration block, my profile and site administration setting. Featured courses consist of narrative, descriptive and expression topic. 


\section{Navigation}

\section{Home}

- My home

$>$ Site pages

> My profile

> My courses

\section{Administration}

Front page settings

Turn editing on

Edit settings

$>$ Users

Filters

> Reports

Backup

Restore

> Question bank

> My profile settings

\section{Site administration}

\section{Figure 8: Admin's Blocks}

Navigation and administration block were on the left column of main page. In the administration block, admin could manage everything on the site. And manage teacher and student's activities. It was hidden from students. It appeared on the front page and each course's home page by default. The bottom of the front page was footer which contained logo picture, featured links and contact information. 
Developing Moodle - Based Interactive Online Media ...

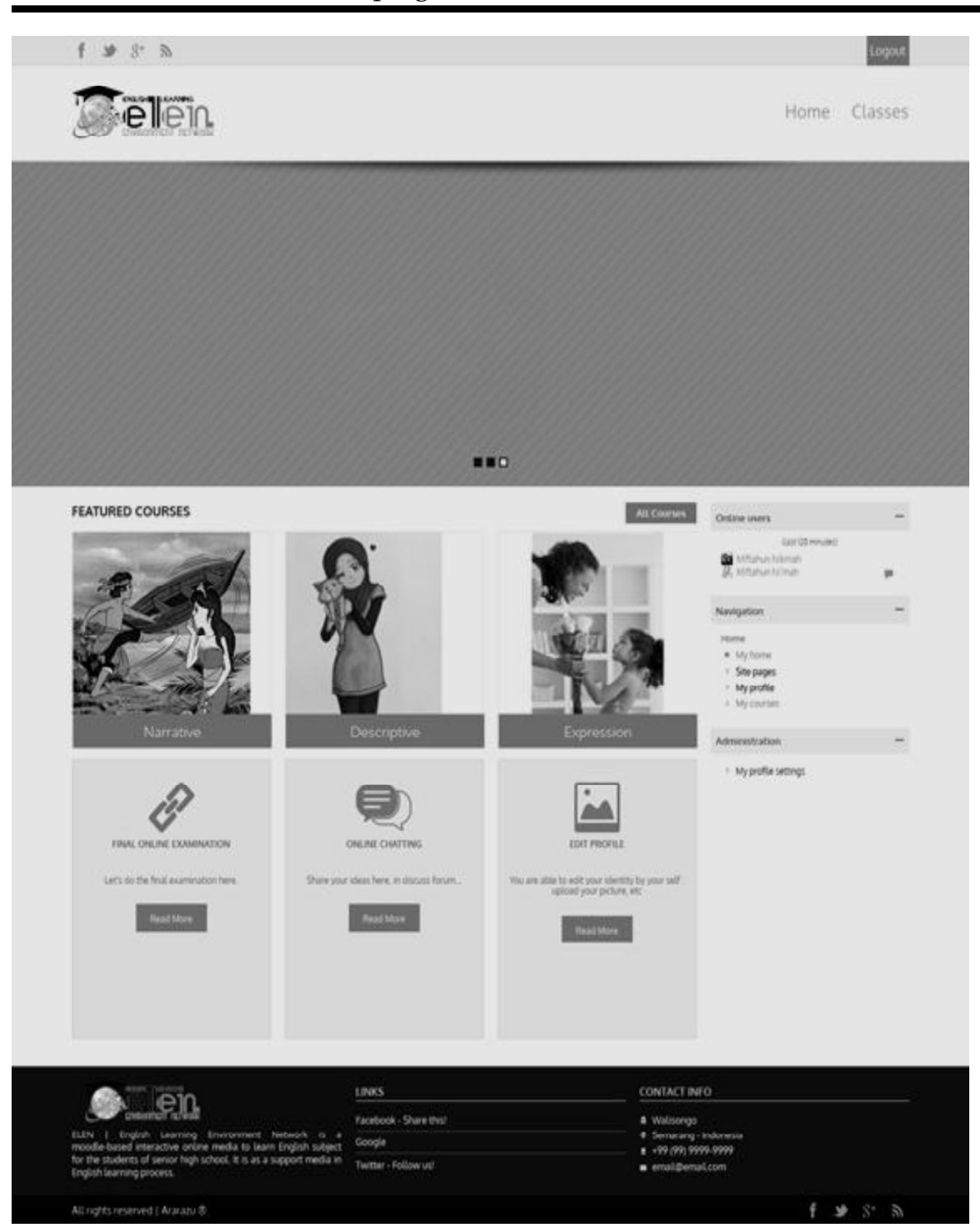

Figure 9: Teacher front page

The header and footer of teacher front page were same content with admin front page. It consisted of logo, button of $\log$ out, home and classes. The main page divided into featured courses, administration block and profile setting. 
Online users

(Last 120 minutes)

\section{Sir Miftahun Nikmah \\ Miftahun Ni'mah}

Navigation

\section{Home}

- My home

$>$ Site pages

> My profile

$>$ My courses

\section{Administration}

\section{My profile settings}

\section{Figure 10: Teacher's Blocks}

Navigation and administration blocks were on the left column. In the administration block, teacher could manage class, give feedback and make report of the courses. Teacher could edit profile from this block. As an adding block, there was online user block to see the users who were in the site for last two hours. 
Developing Moodle - Based Interactive Online Media ...

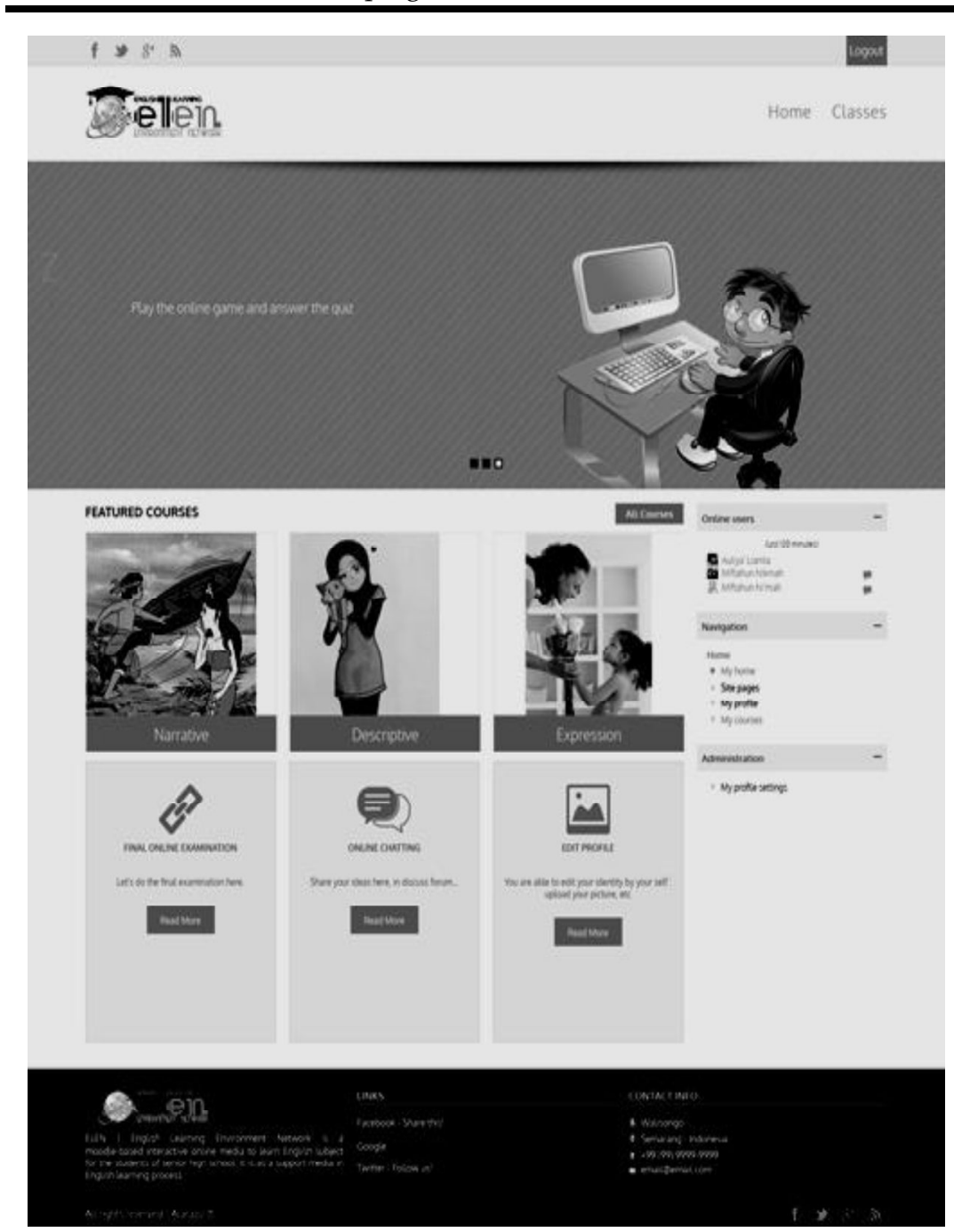

Figure 11: Student's front page

The header and footer of student front page were same content with administrator and teacher front pages. It consisted of logo, button of log out, home and classes. The main page divided into featured courses, navigation and administration block and profile setting. 
Navigation

\section{Home}

- My home

$>$ Site pages

$>$ My profile

$>$ My courses

\section{Administration}

\section{My profile settings}

\section{Figure 12: Student's Blocks}

In the administration block, student could edit profile and check the grade.

After the Moodle - based interactive online media was created in complete design; the next step was testing or expert validations. The material experts in this research were Agus Prayoga, an English lecturer of UIN Walisongo Semarang, and Nasri Sunarsih, an English teacher of SMAN 13 Semarang. The online media experts are Maya Rini Handayani, Communication lecturer of UIN Walisongo Semarang, and Muhammad Tafrikhan, an Information Technology and Communication teacher of SMAN 13 Semarang. The average of the material validation result was $87.5 \%$. It was valid criterion and could be used with little revision.

The students' activities in the preliminary field testing are as follow. They logged into http://elen.airybelle.com. They used the username and passwords given by the teacher. Then, they edited their profiles. In the narrative course page, they discussed the topic, learned the material, played the crossword game and did the final examination. The average of the result of final examination was 80 and the average of crossword game was 73.50. All the students expressed their opinions on discussion forum.

The revision of the opinions and suggestions was given by the validators and it was given by small group of students. It was shown in the following table. 
Developing Moodle - Based Interactive Online Media ...

\begin{tabular}{|c|l|l|}
\hline No & Component & Revision \\
\hline 1 & Less image in front page & $\begin{array}{l}\text { Adding three images on the } \\
\text { front page }\end{array}$ \\
\hline 2 & $\begin{array}{l}\text { Too small font type words } \\
\text { in material page }\end{array}$ & Be larger small font type \\
\hline 3 & $\begin{array}{l}\text { It was limited time to do } \\
\text { the quizzes }\end{array}$ & $\begin{array}{l}\text { Managing time based on the } \\
\text { quiz needed and the lesson } \\
\text { time of English subject }\end{array}$ \\
\hline
\end{tabular}

Table 4.5 Revision based on the student's suggestions

Main field testing was conducted in the different class from the preliminary field testing. In this field testing, they did not edit their profiles in the same time because of limited time. Username and password have been prepared by the teacher for them. So, they just logged in using the appropriate username and password given. They discussed with friends, played the quizzes and did the final examination.

The average of student's questionnaire result was $78.0 \%$ (very good qualifying). So, the Moodle-based interactive online media was valid or suitable for them. The supporting data was taken from their scores. After main field testing was conducted, the students get significant improvement in their score. So the score can be described as follow. In the first quiz, the average score was 89.40 . Whereas, in the final examination, the average score was 79.60 . The average of all courses was 84.50.

\section{Conclusion}

Moodle-based interactive online media in teaching narrative reading as a learning medium can be developed through six steps: need analysis, planning, develop preliminary Moodle-based interactive online media, preliminary field testing, main Moodle-based interactive online media revision and main field testing. The result of developing Moodle-based interactive online media can be accessed at http://elen.airybelle.com. 


\section{REFERENCES}

Bassil, Youssef. 2014. A Simulation Model for the Waterfall Software Development Life Cycle. International Journal of Engineering \& Technology (iJET ). ISSN: 2049-3444,( Vol. 2, No. 5, 2012) available at http://iet-journals.org/archive/2012/ may_vol_2_no_5/255895133318216.pdf at November, $19^{\text {th }}$.

Caladine, Richard. 2008. Enhancing E- Learning with Media Rich Content and Interactions. New York: Information Science publishing.

Cameron, Lynne. Teaching Language to Young Learners. Cambridge: Cambridge.

Cooch, Mary. 2009. Moodle 1.9 for Teaching 7-14 Year Olds Beginner's Guide, Birmingham, UK: Packt Publishing Ltd.

Gall, M, D., \& Borg, W. R. 1983. Educational Research; An Introduction. Fourth Edition. USA: Pearson Education.

Henderson, Allan J. 2003. E-Learning Question and Answer Book. New York: Amacom.

Herrity, Mike. 2014. The Personal learning Environment Moving Platform Beyond the VLE and Share Point Learning Platform. Available at http://mike herrity's blog.com at November, 18th.

Salkintzis, Apostolis K, Ed. 2004. Mobile Internet Enabling Technologies and Services. Washington: Crc Press.

Tarwiyah, Siti. 2008. Modul Game and Songs, Practical Ideas to Teach Language. Semarang: Unpublished.

Williams, Bryan C., Matt Riordan and Martin Dougiamas. 2005. The Manual of Moodle v.1.4.3 for the Moodle.org, USA: Free Software Foundation. 